\title{
Immune checkpoint inhibitors in gastrointestinal malignancies
}

\author{
Vishal Jindal \\ Department of Internal Medicine, St. Vincent Hospital, Worcester, MA, USA \\ Correspondence to: Vishal Jindal, MD. Department of Internal Medicine, St. Vincent Hospital, 123 Summer street, Worcester, MA 01608, USA. \\ Email: vishaljindal87@gmail.com.
}

\begin{abstract}
Gastrointestinal (GIT) tumors are extremely fatal and lethal tumors with limited therapeutic options. Antitumor immunity is new line of research in management of solid tumors. Immune check points are negative regulators of immune system and control the immune response. These checkpoints are exploited by cancer cells. Cancer cells causes early activation of checkpoints and suppress the immune response, and therefore have unchecked growth and metastasis of malignant cells. Immune checkpoint inhibitors (ICIs), downregulates these checkpoints and activate the proliferation of cytotoxic $T$ cells which helps in lysis of tumor cells. ICIs have shown the promising results in management of melanoma, non-small cell lung cancer and renal cell carcinoma. Encouraged by their recent success in solid tumors many clinical trials are ongoing to evaluate their efficacy in GIT tumors. In this article we will try to explain rationale for use of ICIs in GIT tumors. We will summarize the ongoing research, preliminary results and future aspects of ICIs in GIT malignancies.
\end{abstract}

Keywords: Ipilimumab; nivolumab; pembrolizumab; gastrointestinal (GIT) cancers

Submitted Nov 24, 2017. Accepted for publication Dec 27, 2017.

doi: 10.21037/jgo.2018.01.03

View this article at: http://dx.doi.org/10.21037/jgo.2018.01.03

\section{Introduction}

Immune checkpoint inhibitors (ICIs) in gastrointestinal (GIT) tumors-ICIs have revolutionized the cancer management and reignited the hope of treating cancers effectively. GIT tumors are one of the major causes of morbidity and mortality. Esophageal cancers, gastric cancers, pancreatic cancers, hepatocellular carcinoma (HCC) and colorectal cancers (CRC) are widely prevalent and lethal cancers. Currently there are not much effective treatment options for them. ICIs have shown some light and recently emerging data suggest that ICIs may be effective in GIT malignancies. ICIs were reported in 2010 (1) and 2012 (2). In clinical trials they have shown remarkable effect in management of various tumors even in advanced stages. Till now goal of immunotherapy is to enhance the immune system and help it fight against cancers. But it was not a big success due to immune check points. These check point act as brakes on immune system. Along with that, immune system is also suppressed by cancer cells and helps cancer cells in their growth and metastasis. ICIs release these breaks and enhance the activity of immune system to fight against cancers. ICIs act by suppressing the immune check point, which enhances the attachment of Antigen Presenting cells and cytotoxic T cells. This lead to proliferation and increased activity of $\mathrm{T}$ cells against cancers. Some of the targets of ICIs are programmed cell death 1 (PD-1), programmed death ligand 1 (PD-L1) and cytotoxic T lymphocyte associated protein 4 (CTLA4). Cancer immunotherapy is new era in management of cancers and researches have shown its effect in treatment of cancers even in advanced stages. In this article we will discuss the effect of ICIs in GIT malignancies, ongoing research and their future aspects.

\section{Esophageal and gastric cancers}

Despite the recent advances in the field of oncology, prognosis of gastric and esophageal cancers is extremely poor. Esophageal cancer is $6^{\text {th }}$ most common cause of cancer related death and $8^{\text {th }}$ most common cancer worldwide (3). The prognosis of esophageal cancer is extremely poor as 
generally patients present in advanced stages of cancer and therapeutic options are limited. Gastric cancer is $2^{\text {nd }}$ most common cause of cancer related death worldwide in 2012 and $5^{\text {th }}$ most common malignancy (3). Systemic therapy for metastatic disease is basically platinum $/ 5$ fluoropyrimidine based. With addition of anthracyclines/ taxanes there is survival benefit in some patients (4-6). Anti Her-2 monoclonal antibody (7), trastuzumab and antivascular endothelial growth factor receptor 2 (VEGFR2) monoclonal antibody, ramucirumab (8) are important additions in the management of Esophageal and gastric cancers. But overall survival benefit is very low. Recent clinical experience, research and available data are showing that ICIs is the emerging therapy for esophageal and gastric cancers.

\section{Rationale for ICIs in esophageal and gastric cancers}

\section{PD-L1/PD-L2 distribution}

PD-L1 and PD-L2 are receptors present on tumor cells and on binding with PD-1, they inhibit the $T$ cell activation and inactivates the immune system. ICIs acting on PD-L1 and PD-L2 inhibit this interaction and releases brakes of immune system and leads to activation and proliferation of cytotoxic $\mathrm{T}$ lymphocytes and helps in removing cancer cells. PD-L1 and PD-L2 are expressed on many cells like multiple myeloma, renal cell carcinoma, breast, colon bladder and lung cancer (9-11). Currently ICIs therapy is approved in melanoma, non-small cell lung cancer (NSCLC) and renal cell carcinoma (12-14) and all three of them have shown high level of PD-L1 expression. Study done on esophageal squamous cell carcinoma patients has found that $43.9 \%$ patients had PD-L1 or PD-L2 expression (15). Similarly, in gastric carcinoma patients PD-L1 expression was $42.2 \%$ (16). Studies have shown convincing results regarding expression of PD-L1 and PD-L2 in esophageal and gastric cancers.

\section{Tumor infiltration lymphocytes (TILs)}

It is the microenvironment of the tumor which determines the effect of ICIs, especially TIL's. Multiple studies have shown a correlation between TILs density and favorable outcome in patients with breast ovarian and CRC (17-20). In esophageal and gastric cancers, it has been suggested through various preclinical models, that the density of TILs is higher in early stages of cancer but due to selection of least immunogenic cancer cell clones in advanced stages they are less immunogenic $(21,22)$. Further studies are needed to understand the relationship of TILs density and immunotherapy response to define in which patients ICIs therapy will be helpful.

\section{Clinical experience and ongoing research of ICIs in esophageal and gastric cancers}

There are few studies regarding ICIs in esophageal and gastric cancers. In ASCO 2016, updated results of phase 1b KEYNOTE-28 study on advanced esophageal carcinoma cohort were presented (23). This study was for evaluation of pembrolizumab in solid tumors expressing PD-L1. It showed that in patients with PD-L1 positive heavily treated esophageal cancer, overall response rate was $30.4 \%$ and Progression free survival was $21.7 \%$ at 1 year. These are promising results. In ESMO conference, results of role of pembrolizumab in advanced PD-1 positive gastric cancers were presented (24). In that study total 39 patients were enrolled and analysis showed that overall response rate was $22 \%$ in median response duration was 24 weeks. After these results phase 2 trial was started, KEYNOTE-059 of cisplatin/5FU with pembrolizumab. It showed encouraging efficacy and manageable safety after 2 prior lines of therapy in patients with advanced gastric and gastroesophageal junction cancers. Currently phase 2 and phase 3 studies are going on regarding use of nivolumab and pembrolizumab in esophageal and gastric cancers. Their details are mentioned in (Table 1).

\section{Future of ICIs in gastroesophageal cancers}

\section{Combination of PD-1 and CTLA-4 inhibitors}

Both are ICIs and act on different receptors. There may be synergistic effect of their combination and it can enhance the efficacy of ICIs.

\section{ICIs with chemotherapy}

In esophageal cancer patients a study (NCT03143153) is going on which compares the effect of combination of ICIs (nivolumab and ipilimumab) with ICI (nivolumab) and chemotherapy (5FU plus cisplatin) with chemotherapy (5FU plus cisplatin) alone. Chemotherapy destroys tumor cells and releases intracellular RNA, peptides, proteins, DNA which act as a tumor antigen and increases the immune response of body against cancers. If ICIs are also given with them, they further enhance the immune system and helps in clearing cancer cells. 
Table 1 Clinical trials of immune checkpoint inhibitors in gastroesophageal cancers (https://clinicaltrials.gov)

\begin{tabular}{|c|c|c|c|c|c|}
\hline NCT number & Title & Phase & Conditions & Interventions & $\begin{array}{l}\text { Outcome } \\
\text { measures }\end{array}$ \\
\hline NCT03322267 & $\begin{array}{l}\text { Adjuvant pembrolizumab for patients with } \\
\text { locally advanced esophageal squamous cell } \\
\text { carcinoma at high risk of recurrence }\end{array}$ & 2 & $\begin{array}{l}\text { Esophageal squamous cell } \\
\text { carcinoma }\end{array}$ & Pembrolizumab & $\begin{array}{l}\text { RFS, OS, } \\
\text { TEAE }\end{array}$ \\
\hline NCT03278626 & $\begin{array}{l}\text { Immune checkpoint therapy with Nivolumab } \\
\text { esophageal squamous cell carcinoma }\end{array}$ & 1,2 & $\begin{array}{l}\text { Esophageal squamous cell } \\
\text { carcinoma }\end{array}$ & $\begin{array}{l}\text { Nivolumab + carboplatin } \\
\text { /paclitaxel + radiation }\end{array}$ & UT \\
\hline NCT03143153 & $\begin{array}{l}\text { A study to evaluate efficacy in subjects with } \\
\text { esophageal cancer treated with nivolumab } \\
\text { and ipilimumab or nivolumab combined with } \\
\text { fluorouracil plus cisplatin versus fluorouracil } \\
\text { plus cisplatin }\end{array}$ & 3 & Various advanced cancer & $\begin{array}{l}\text { Nivolumab, ipilimumab, } \\
\text { cisplatin, fluorouracil }\end{array}$ & $\begin{array}{l}\text { OS, PFS, } \\
\text { ORR }\end{array}$ \\
\hline NCT03044613 & $\begin{array}{l}\text { Nivolumab or nivolumab/ipilimumab prior } \\
\text { to chemoradiation plus nivolumab with II/III } \\
\text { gastro/esophageal cancer }\end{array}$ & 1 & $\begin{array}{l}\text { Gastric cancer, esophageal } \\
\text { cancer, gastroesophageal } \\
\text { cancer }\end{array}$ & $\begin{array}{l}\text { I Nivolumab, ipilimumab, } \\
\text { carboplatin, paclitaxel, } \\
\text { radiation }\end{array}$ & $\begin{array}{l}\text { RR, TRAE,OS, } \\
\text { RFS }\end{array}$ \\
\hline NCT02998268 & $\begin{array}{l}\text { Study of pembrolizumab in locally advanced } \\
\text { esophageal adenocarcinoma }\end{array}$ & 2 & $\begin{array}{l}\text { Esophageal } \\
\text { adenocarcinoma }\end{array}$ & $\begin{array}{l}\text { Pembrolizumab, taxol, } \\
\text { carboplatin }\end{array}$ & DFS, RR, OS \\
\hline NCT02971956 & $\begin{array}{l}\text { Pembrolizumab in refractory advanced } \\
\text { esophageal cancer }\end{array}$ & 2 & Esophageal cancer & Pembrolizumab & $\begin{array}{l}\text { RR, OS, PFS, } \\
A E\end{array}$ \\
\hline NCT02954536 & $\begin{array}{l}\text { Phase II trial of pembrolizumab with } \\
\text { trastuzumab and chemotherapy in advanced } \\
\text { her2 positive esophagogastric cancer }\end{array}$ & 2 & $\begin{array}{l}\text { Esophageal cancer, gastric } \\
\text { cancer }\end{array}$ & $\begin{array}{l}\text { Pembrolizumab, } \\
\text { trastuzumab, capecitabine, } \\
\text { cisplatin, oxaliplatin, } \\
\text { 5-fluorouracil }\end{array}$ & PFS \\
\hline NCT02689284 & $\begin{array}{l}\text { Combination margetuximab and } \\
\text { pembrolizumab for advanced, metastatic } \\
\text { her2(+) gastric or gastroesophageal junction } \\
\text { cancer }\end{array}$ & 1,2 & $\begin{array}{l}\text { Gastric cancer and } \\
\text { esophageal cancer }\end{array}$ & $\begin{array}{l}\text { Margetuximab, } \\
\text { pembrolizumab }\end{array}$ & ATA, PFS, OS \\
\hline NCT02642809 & $\begin{array}{l}\text { Pembrolizumab with locally delivered } \\
\text { radiation therapy for the treatment of } \\
\text { metastatic esophageal cancers }\end{array}$ & 1 & Esophageal cancer & $\begin{array}{l}\text { Pembrolizumab, } \\
\text { brachytherapy, endoscopic } \\
\text { biopsy }\end{array}$ & ATA, PFS, OS \\
\hline NCT02569242 & $\begin{array}{l}\text { Study of nivolumab in unresectable advanced } \\
\text { or recurrent esophageal cancer }\end{array}$ & & Esophageal cancer & $\begin{array}{l}\text { Nivolumab, docetaxel/ } \\
\text { paclitaxel }\end{array}$ & $\begin{array}{l}\text { OS, PFS, RR, } \\
\text { DOR AE }\end{array}$ \\
\hline NCT01585987 & $\begin{array}{l}\text { An efficacy study in gastric and } \\
\text { gastroesophageal junction cancer comparing } \\
\text { Ipilimumab versus standard of care } \\
\text { immediately following first line chemotherapy }\end{array}$ & 2 & $\begin{array}{l}\text { Adenocarcinoma } \\
\text { of the gastric and } \\
\text { gastroesophageal junction }\end{array}$ & Ipilimumab & $\begin{array}{l}\text { irPFS, PFS, } \\
\text { OS, irBOR }\end{array}$ \\
\hline
\end{tabular}

UT, unacceptable toxicity; pCR, pathological complete response rate; ATA, antitumor activity; irBOR, immune-related best overall response; RFS, relapse free survival; OS, overall survival; TEAE, treatment-emergent adverse events; AE, adverse events; DOR, duration of response; ORR, overall response rate; RR, response rate; DFS, disease free survival; irPFS, immune related progression free survival; PFS, progression free survival; TRAE, treatment related adverse events. 


\section{ICIs with radiotherapy}

Some trials regarding pembrolizumab with locally delivered radiation therapy for the treatment of metastatic esophageal cancers (NCT02642809) are also running. It will be a good combination therapy and will work on same principle as combination of chemotherapy with ICIs. Radiation therapy kills cancer cells and release inflammatory markers and if ICIs are also given along with them they will aggravate the immune response and will help in fighting cancer cells.

\section{ICIs with Anti HER-2 monoclonal antibody}

Currently phase II trial of pembrolizumab with trastuzumab and chemotherapy in advanced HER2 positive esophagogastric cancer (NCT02954536) is going on. Trastuzumab has immune modulating properties that may be helpful in more infiltration of tumor microenvironment with immune cells and increase efficacy of ICIs.

\section{HCC}

HCC is one of the most dreadful tumors, most of the times it is associated with chronic liver disease which make it more lethal and difficult to treat. Resection of the tumor is preferred therapy but most of the time, due to extent of disease and liver dysfunction, it's not an option. Patients who have advanced tumors, we go for radiofrequency ablation and chemoembolization. Liver transplantation is another option for locally extensive tumors, but chances of rejection and immunosuppression are some drawbacks of it. Chemotherapy is not used commonly as most of the HCC present in advanced stage and by that time they are refractory to treatment. Sorafenib (25) is the only FDA proved drug for HCC, but efficacy and overall response rate is very low. So in all we don't have enough tools in our armamentarium for effective management of HCC. ICIs have recently shown promising benefit in HCC patients a tumor which is resistant to traditional form of chemotherapy.

\section{Rationale of ICIs in HCC}

For a long time, our understanding regarding immune system was very limited. It was believed that primary role of immune system is to prevent invasion of body from foreign antigens. There is immune surveillance system which detects cancer cells and destroys them with the help of natural killer (NK) cells and cytotoxic T lymphocytes (CTLs). But now it has been well accepted that interactions between immune cells and cancer cells is complex and more dynamic than it was thought in the past. Host Immune system causes inflammation and infiltration of cancer tissue with myeloid derived suppressor cells (MDSCs), tumor-associated macrophages (TAM), regulatory $\mathrm{T}$ cells (Tregs) and cancer associated fibroblasts (CAF) (26). This infiltration of inflammatory cells has shown to promote proliferation of tumor cells along with that they also help in invasion and metastasis (27).

The intrinsic hepatic microenvironment has made liver an immune tolerogenic organ. There are multiple immune responses which promote the cancer progression like change in functional ability, change in cytokine level and expression of immune receptors or ligands. Due to Tregs, impairment of $\mathrm{T}$ cell function and upregulation of Immune check point pathways, immune system is unable to recognize tumor cells (28-34). These factors together downregulate immune response and promote activity of tumor cells. Therefore, immune system which is defense mechanism of body is modified by tumor cells, they make immune system work in their favor and promote growth of cancer cells. ICIs can reverse this effect, they can activate and proliferate CTLs and help in degradation and lysis of cancer cells.

\section{Clinical experience and ongoing research in ICIs in HCC}

In 2015ASCO, interim results of phase 1 and phase 2 trial of nivolumab in patients with advanced HCC were presented (35). In this trial, administered dose of nivolumab was $3 \mathrm{~mL} / \mathrm{kg}$ in patients with hepatitis $\mathrm{C}$ virus, hepatitis $\mathrm{B}$ virus and uninfected patients, up to $10 \mathrm{~mL} / \mathrm{kg}$ dose is safe in uninfected patients. Sample size of this study was 47 out of which $70 \%$ patients had extrahepatic metastasis, $13 \%$ had vascular invasion and $68 \%$ had history of use of Sorafenib treatment. Out of 47 patients therapy was discontinued in 30 patients. 26 developed progression of disease, 2 had adverse reaction and 2 patients had complete response. The therapy was continued in 17 patients. Approximately 19\% (8 patients) responded to therapy with nivolumab. Among them, 2 had complete recovery while 6 patients had partial response. Progressive disease occurred in 33\% (14 patients) and disease control rate was $67 \%$ (28 patients). Overall half of total patients had stable disease with longest lasting 17 months. At 12 months, $62 \%$ of people were surviving with HCC. Treatment related adverse events occurred in $68 \%$ of patients. Increase in liver enzymes was the most common side effect. Elevated aspartate aminotransferase is seen in $11 \%$, elevated alanine transferase in $9 \%$ and elevated lipase in $2 \%$ of patients. Considering all together 
Nivolumab produced durable response in HCC patients. Overall survival of $62 \%$ at 1 year, reduction in tumor size after 48 weeks, complete response in 3 months in 2 patients and maintainence of response at 18 months even after stopping nivolumab are promising results. Further clinical trials are going on regarding role of ICIs in HCC (Table 2).

\section{Future of ICIs in HCC}

\section{Combination of ICIs}

Combination of ICIs, acting on different receptors should have a synergistic effect combined therapy should enhance the activity of immune response to a greater extent and will have better response. Study evaluating Nivolumab alone versus Nivolumab plus Ipilimumab in patients with resectable and potentially resectable $\mathrm{HCC}$ is going on (NCT03222076).

\section{ICIs combined therapy with transcatheter arterial} trans-embolization

Their combination should have synergistic effects. Currently study is going on regarding combination of TATE Trans-arterial tirapazamine embolization and PD-1 Inhibitor in liver Cancer. (NCT03259867).

ICIs as neoadjuvant and adjuvant after resection and ablation

ICIs trials are also going on as adjuvant and neoadjuvant therapy after resection and ablation. A pilot study of combined immune checkpoint inhibition in combination with ablative therapies in patients with HCC or Biliary tract carcinomas (NCT02821754) is recruiting patients.

\section{ICIs with chemotherapy}

Trials on combination of chemotherapy and ICIs in HCC are also going on. One of them is Guadecitabine and Durvalumab in treating patients with advanced liver, pancreatic, bile duct, or gallbladder cancer (NCT03257761)

\section{ICIs with radiotherapy}

Actively recruiting study for this combination is Stereotactic body radiotherapy (SBRT) followed by nivolumab or ipilimumab with nivolumab in unresectable HCC (NCT03203304).

\section{Pancreatic carcinoma}

Across the world Pancreatic cancer is one of the most lethal malignant neoplasms and leading cause of mortality $(3,36,37)$. Based on GLOBOCAN 2012 estimates, pancreatic cancer is $11^{\text {th }}$ most common cancer and it is $7^{\text {th }}$ most common cause of cancer mortality in both sexes together (3). It accounts for more than 331,000 deaths per year. Estimated 5-year survival rate is less than 5\% (38). Pancreatic cancer is characterized by delayed diagnosis, resistance to therapy, highly metastatic and high mortality. Most of the time pancreatic cancer at time of diagnosis is advanced and metastasized to different organs so not amenable to surgery and most of these patients end up in getting palliative therapy. The existing treatment modalities, including chemotherapy and surgical resection, can prolong survival of patients but it cannot be curative. ICIs have revolutionized the cancer management and showed a promising response in advanced solid tumors. Some studies have shown the benefit of ICIs in pancreatic cancer and lot of studies are going on. If ICIs inhibitors improve survival of pancreatic cancer patients it will be a new paradigm.

\section{Rationale of ICIs in pancreatic cancer}

Similar to HCC, pancreatic cancer microenvironment consists of many inflammatory cells. This infiltration of inflammatory cells can promote the tumor growth and immunosuppressive in function. Some of them are MDSCs, TAM, Tregs, natural killer cells. Tumor cells also avoid detection by immune system by various mechanisms such as IL-10, Vascular endothelial growth factor, upregulation of immune check points, downregulation of major histocompatibility factor (MHC). Immune system plays a major role in pancreatic cancer and ICIs can enhance activity of immune system against cancer cells and therefore they can be a great treatment modality for pancreatic cancer.

\section{Clinical experience and ongoing research}

Currently lot of research is going on use of ICIs in pancreatic cancers. Initially a phase 2 trial was done for Ipilimumab on locally advanced and metastatic pancreatic cancer by Royal et al. (39) According to standard response evaluation criteria in solid tumors (RECIST) it did not show any benefit. But one patient showed delayed response in both metastatic and primary tumors. As per preclinical data ipilimumab has synergistic effect with GVAX. GVAX is a granulocyte macrophage colony stimulating factor (GM-CSF) gene transfected tumor cell vaccine which 
Table 2 Clinical trials of immune checkpoint inhibitors in hepatocellular carcinoma (https://clinicaltrials.gov)

\begin{tabular}{|c|c|c|c|c|c|}
\hline NCT number & Title & Phase & Conditions & Interventions & $\begin{array}{l}\text { Outcome } \\
\text { measures }\end{array}$ \\
\hline NCT03299946 & $\begin{array}{l}\text { Feasibility and efficacy of neoadjuvant cabozantinib } \\
\text { plus nivolumab (Cabonivo) followed by definitive } \\
\text { resection for patients with locally advanced } \\
\text { hepatocellular carcinoma }\end{array}$ & 1 & $\begin{array}{l}\text { Locally advanced } \\
\text { hepatocellular } \\
\text { carcinoma }\end{array}$ & $\begin{array}{l}\text { Cabozantinib, } \\
\text { nivolumab }\end{array}$ & $\begin{array}{l}\text { AE, CR, ORR, } \\
\text { DFS }\end{array}$ \\
\hline NCT03298451 & $\begin{array}{l}\text { Study of durvalumab and tremelimumab as first-line } \\
\text { treatment in patients with unresectable hepatocellular } \\
\text { carcinoma }\end{array}$ & 3 & $\begin{array}{l}\text { Hepatocellular } \\
\text { carcinoma }\end{array}$ & $\begin{array}{l}\text { Durvalumab, } \\
\text { tremelimumab }\end{array}$ & $\begin{array}{l}\text { OS, TTP, ORR. } \\
\text { DCR, DOR, PK }\end{array}$ \\
\hline NCT03259867 & Combination of TATE and PD-1 inhibitor in liver cancer & 2 & $\begin{array}{l}\text { Hepatocellular, } \\
\text { colorectal } \\
\text { neoplasms }\end{array}$ & $\begin{array}{l}\text { Nivolumab, } \\
\text { pembrolizumab, trans- } \\
\text { arterial tirapazamine } \\
\text { embolization }\end{array}$ & $\begin{array}{l}\text { RR, ORR, DOR, } \\
\text { PFS, OS }\end{array}$ \\
\hline NCT03257761 & $\begin{array}{l}\text { Guadecitabine and durvalumab in treating patients with } \\
\text { advanced liver, pancreatic, bile duct, or gallbladder } \\
\text { cancer }\end{array}$ & 1 & $\begin{array}{l}\text { Liver, pancreatic, } \\
\text { bile duct, } \\
\text { gallbladder cancer }\end{array}$ & $\begin{array}{l}\text { Durvalumab, } \\
\text { guadecitabine }\end{array}$ & AE, OS, PFS \\
\hline NCT03203304 & $\begin{array}{l}\text { Study of stereotactic body radiotherapy (SBRT) } \\
\text { followed by Nivolumab or Ipilimumab with nivolumab } \\
\text { in unresectable hepatocellular carcinoma }\end{array}$ & 1 & $\begin{array}{l}\text { Hepatocellular } \\
\text { carcinoma }\end{array}$ & $\begin{array}{l}\text { Nivolumab, } \\
\text { ipilimumab }\end{array}$ & $\begin{array}{l}\text { AE, ORR, PFS, } \\
\text { OS }\end{array}$ \\
\hline NCT03071094 & $\begin{array}{l}\text { A trial to evaluate the safety and efficacy of the combination } \\
\text { of the oncolytic immunotherapy Pexa-Vec with the PD-1 } \\
\text { receptor blocking antibody Nivolumab in the first-line } \\
\text { treatment of advanced hepatocellular carcinoma }\end{array}$ & 1,2 & $\begin{array}{l}\text { Hepatocellular } \\
\text { carcinoma }\end{array}$ & $\begin{array}{l}\text { Pexastimogene } \\
\text { devacirepvec (Pexa } \\
\text { Vec), nivolumab }\end{array}$ & $\begin{array}{l}\text { Phase I part: } \\
\text { DLT; Phase Ila } \\
\text { part: ORR, DCR, } \\
\text { OS }\end{array}$ \\
\hline NCT03033446 & $\begin{array}{l}\text { Study of Y90-radioembolization with nivolumab in } \\
\text { Asians with hepatocellular carcinoma }\end{array}$ & 2 & $\begin{array}{l}\text { Hepatocellular } \\
\text { carcinoma }\end{array}$ & $\begin{array}{l}\text { Y-90, } \\
\text { radioembolization, } \\
\text { nivolumab }\end{array}$ & $\begin{array}{l}\text { RR, DOR, PFS, } \\
\text { OS, }\end{array}$ \\
\hline NCT02576509 & $\begin{array}{l}\text { An investigational immuno-therapy study of Nivolumab } \\
\text { compared to sorafenib as a first treatment in patients } \\
\text { with advanced hepatocellular carcinoma }\end{array}$ & 3 & $\begin{array}{l}\text { Hepatocellular } \\
\text { carcinoma }\end{array}$ & Nivolumab, sorafenib & $\begin{array}{l}\text { OS, ORR, PFS, } \\
\text { PD }\end{array}$ \\
\hline NCT02519348 & $\begin{array}{l}\text { A study of MEDI } 4736 \text { with tremelimumab, MEDI } 4736 \\
\text { or tremelimumab monotherapy in unresectable } \\
\text { hepatocellular carcinoma }\end{array}$ & 2 & $\begin{array}{l}\text { Hepatocellular } \\
\text { carcinoma }\end{array}$ & $\begin{array}{l}\text { MEDI4736, } \\
\text { tremelimumab }\end{array}$ & $\begin{array}{l}\text { AE, DLT, DOR, } \\
\text { OS, PFS, DCR }\end{array}$ \\
\hline NCT01853618 & $\begin{array}{l}\text { Tremelimumab with chemoembolization or ablation for } \\
\text { liver cancer }\end{array}$ & 1 & $\begin{array}{l}\text { Liver cell } \\
\text { carcinoma }\end{array}$ & $\begin{array}{l}\text { Tremelimumab, } \\
\text { radiofrequency } \\
\text { ablation (RFA), SBRT, } \\
\text { cryoablation }\end{array}$ & $\mathrm{AE}$ \\
\hline NCT01658878 & $\begin{array}{l}\text { An immuno-therapy study to evaluate the effectiveness, } \\
\text { safety and tolerability of nivolumab or nivolumab } \\
\text { in combination with other agents in patients with } \\
\text { advanced liver cancer }\end{array}$ & 1,2 & $\begin{array}{l}\text { Hepatocellular } \\
\text { carcinoma }\end{array}$ & $\begin{array}{l}\text { Nivolumab, sorafenib, } \\
\text { ipilimumab, } \\
\text { cabozantinib }\end{array}$ & AE, SAE, ORR, \\
\hline
\end{tabular}

DCR, disease control rate; AE, adverse events; SAE, serious adverse events; PFS, progression free survival; OS, overall survival; ORR, overall response rate; RR, response rate; DOR, duration of response; DLT, incidence of dose, limiting toxicities; CR, complete response; DFS, disease free survival; PD, pharmacodynamics; TTP, time to progression; PK, pharmacokinetics; DLT, dose limited toxicities; MTD, maximum tolerated dose. 
stimulates immune response against cancer cells. So a study is conducted comparing combination of Ipilimumab and GVAX with Ipilimumab alone (40). It has two arms only Ipilimumab was given and in arm B Ipilimumab and GVAX was given to pancreatic cancer patients. In arm A, 2 patients had stable disease for 7 and 22 weeks and in arm B three patients had stable disease. Two of them had stabilization for 59 and 71 weeks, one has 17 weeks of regression. In arm A median overall survival was 3.6 months and 1-year survival was $7 \%$. In arm B median overall survival was 5.7 months and 1 -year survival was $27 \%$. The study was inconclusive whether Ipilimumab alone or in combination has better outcome. But in patients with longer life expectancy ICIs can have some beneficial effects. List of clinical trials for ICI in pancreatic cancer is shown in Table 3.

\section{Future of ICIs in pancreatic cancer}

\section{Combination therapy of ICIs}

Active studies for this combination are nivolumab and ipilimumab and radiation therapy in high colorectal and pancreatic cancer (NCT03104439), durvalumab and tremelimumab in combination with first-line chemotherapy in advanced solid tumors (NCT02658214).

\section{ICIs with chemotherapy}

Active studies for this combination are azacitidine and pembrolizumab in pancreatic cancer (NCT03264404), defactinib combined with pembrolizumab and gemcitabine in patients with advanced cancer (NCT02546531),

\section{ICIs with radiotherapy}

Active study for this combination is immune checkpoint inhibition in combination with radiation therapy in pancreatic cancer patients (NCT02866383).

\section{ICIs with vaccine}

Active studies for combination of ICIs and vaccine are neoadjuvant/adjuvant GVAX pancreas vaccine with or without nivolumab trial for surgically resectable pancreatic cancer (NCT02451982), study of CRS-207, nivolumab, and ipilimumab with or without GVAX pancreas vaccine in patients with pancreatic cancer (NCT03190265).

\section{CRC}

It is one of the most prevalent and lethal cancer in the world. It is third most common diagnosed cancer in males and second in females (41). In USA approximately 135,430 new cases of large bowel cancer are diagnosed every year and out of that 95,520 are colon and rest are rectal cancers (42). CRC accounts for $8 \%$ of all cancer deaths. In addition to chemotherapy and surgical resection, recent therapeutic approaches are vascular endothelial growth factor (VEGF) and epidermal growth factor receptor (EGFR) targeted agents (43). These targeted therapies have improved survival to 30 months in patients with metastatic disease. However, lot of research is going on to further improve the outcome of advanced colorectal carcinoma. Early trial results of ICIs in CRC with micro satellite instability (MSI) are promising. Clinical trials are going on to confirm these preliminary results.

\section{Rationale of ICIs in CRC}

CRC is divided into three types sporadic, familial and hereditary. Sporadic is associated with lifestyle like alcohol, smoking, diet and obesity and it constitute $70-75 \%$. Familial and hereditary is associated with germ line mutation and constitutes $20 \%$ and $5 \%$, respectively (44-46). Mismatch repair (MMR) proteins function as security guard during cell replication, if there is any kind of mismatch due to insertion and deletion by DNA polymerase, these proteins correct it and decreases the chances of mutation in cell replication. These replication errors are more common in repetitive DNA sequences known as Microsatellites. Therefore, if there are mutation is MMR proteins, DNA replication will be inaccurate and it leads to MSI (47). Lynch syndrome is an autosomal dominant disorder, caused by germline mutation in MMR genes like MSH6, MLH1, MSH2 (48). These mutations play an important role in causation in CRC in Lynch syndrome patients by MSI (49). The molecular mechanism behind MSI is inactivation of MLH1 by hypermethylation of promoter area (50). Number of mutation required for CRC in MSI is much higher than microsatellite stability (MSS) (51). High no. of mutations increases the no. of neoantigen and enhances the immune response. This enhanced immune response increases the no of $\mathrm{CD}^{+}$ $\mathrm{T}$ cells, $\mathrm{CD} 8^{+} \mathrm{T}$ cells, lytic enzymes and upregulates costimulatory molecules for Antigen presenting cells in the tumor microenvironment (52-57). Due to high immunogenic nature of CRC and high density of TILs, chances for success of ICIs in CRC is very high. 
Table 3 Clinical trials of immune checkpoint inhibitors in pancreatic cancer (https://clinicaltrials.gov)

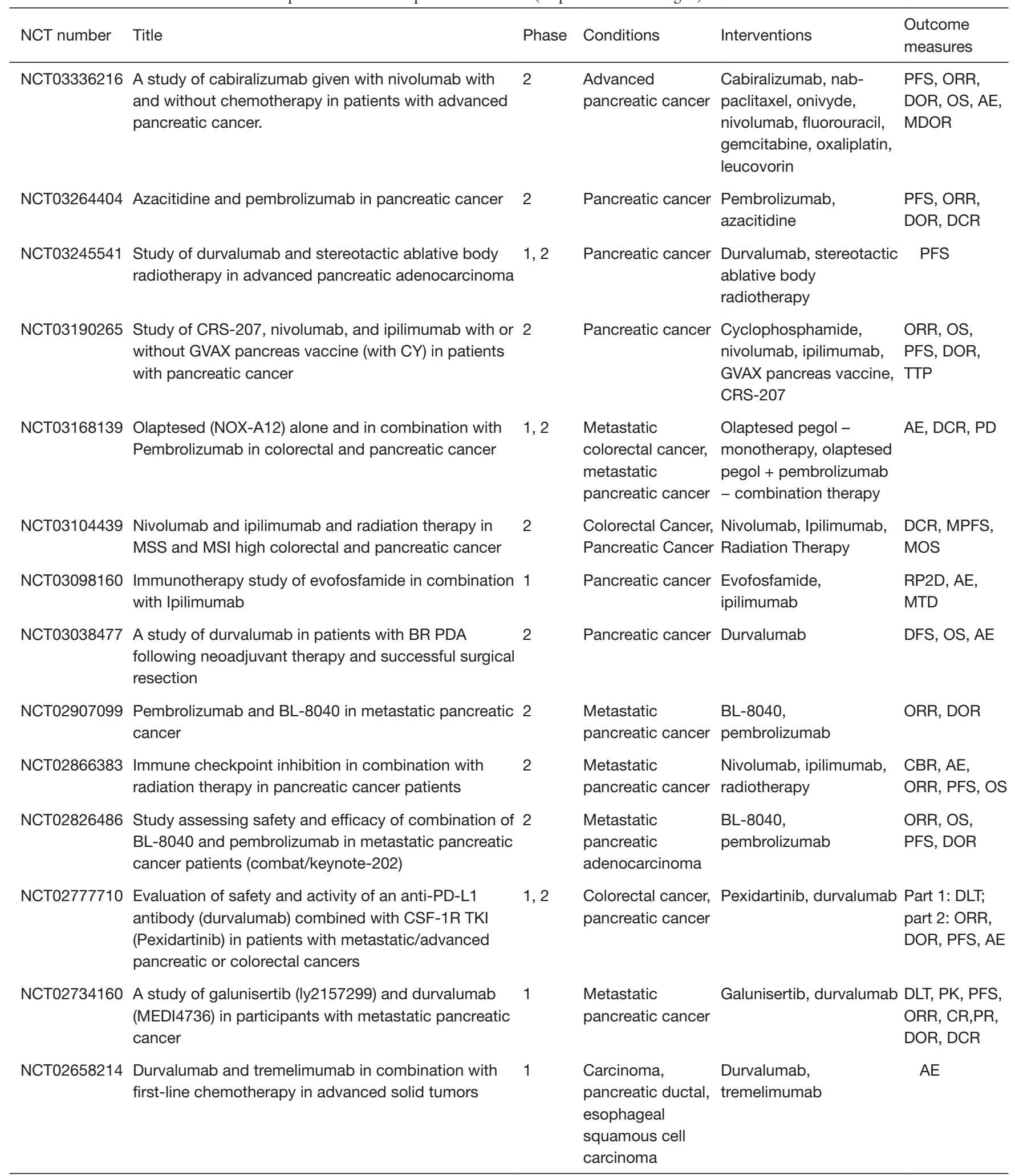

Table 3 (continued) 
Table 3 (continued)

\begin{tabular}{|c|c|c|c|c|c|}
\hline NCT number & Title & Phase & Conditions & Interventions & $\begin{array}{l}\text { Outcome } \\
\text { measures }\end{array}$ \\
\hline NCT02648282 & $\begin{array}{l}\text { Study with CY, pembrolizumab, GVAX, and SBRT in } \\
\text { patients with locally advanced pancreatic cancer }\end{array}$ & 2 & Pancreatic cancer & $\begin{array}{l}\text { Cyclophosphamide, } \\
\text { GVAX, pembrolizumab, } \\
\text { SBRT }\end{array}$ & $\begin{array}{l}\text { DMFS, OS, } \\
\text { LPFS, irAE }\end{array}$ \\
\hline NCT02558894 & $\begin{array}{l}\text { Phase II study of MEDI } 4736 \text { monotherapy or in } \\
\text { combinations with Tremelimumab in metastatic } \\
\text { pancreatic ductal carcinoma }\end{array}$ & 2 & $\begin{array}{l}\text { Metastatic } \\
\text { pancreatic ductal } \\
\text { adenocarcinoma }\end{array}$ & $\begin{array}{l}\text { MEDI4736 monotherapy, } \\
\text { tremelimumab }\end{array}$ & $\begin{array}{l}\text { RR, DOR, } \\
\text { DCR, PFS, PK }\end{array}$ \\
\hline NCT02546531 & $\begin{array}{l}\text { Defactinib combined with pembrolizumab and } \\
\text { gemcitabine in patients with advanced cancer }\end{array}$ & 1 & $\begin{array}{l}\text { Advanced solid } \\
\text { tumors, pancreatic } \\
\text { cancer }\end{array}$ & $\begin{array}{l}\text { Defactinib, } \\
\text { pembrolizumab, } \\
\text { gemcitabine }\end{array}$ & $\begin{array}{l}\text { ORR, PFS, } \\
\text { OS, irPFS }\end{array}$ \\
\hline NCT02451982 & $\begin{array}{l}\text { Neoadjuvant/adjuvant GVAX pancreas vaccine (with } \\
\text { CY) with or without nivolumab trial for surgically } \\
\text { resectable pancreatic cancer }\end{array}$ & 1,2 & Pancreatic cancer & $\begin{array}{l}\text { Cyclophosphamide, } \\
\text { GVAX, nivolumab }\end{array}$ & irAE, OS, DFS \\
\hline NCT02305186 & $\begin{array}{l}\text { Safety and immunological effect of pembrolizumab in } \\
\text { resectable or borderline resectable pancreatic cancer }\end{array}$ & 1,2 & Pancreatic cancer & $\begin{array}{l}\text { Pembrolizumab, } \\
\text { neoadjuvant } \\
\text { chemoradiation }\end{array}$ & $\begin{array}{l}\text { DLTs, DFS, } \\
\text { OS, RR }\end{array}$ \\
\hline NCT00836407 & $\begin{array}{l}\text { Ipilimumab }+/- \text { vaccine therapy in treating patients } \\
\text { with locally advanced, unresectable or metastatic } \\
\text { pancreatic cancer }\end{array}$ & 1 & Pancreatic cancer & Ipilimumab & $\begin{array}{l}\text { OS, ORR, } \\
\text { irBOR, PFS, } \\
\text { AE and ORR }\end{array}$ \\
\hline NCT00112580 & $\begin{array}{l}\text { MDX-010 in treating patients with stage IV pancreatic } \\
\text { cancer that cannot be removed by surgery }\end{array}$ & 2 & Pancreatic cancer & Ipilimumab & CR, PR \\
\hline
\end{tabular}

DCR, disease control rate; AE, adverse events; RP2D, recommended phase II dose; PFS, progression free survival; OS, overall survival; ORR, overall response rate; RR, response rate; DOR, duration of response; DLT, incidence of dose, limiting toxicities; CR, complete response; DFS, disease free survival; PD, pharmacodynamics; MPFS, median progression free survival; MOS, median overall survival; irORR, immune related overall response rate; PK, pharmacokinetics; MDOR, median duration of response; DCR, disease control rate TTP, time to progression; MTD, maximum tolerated dose; CBR, clinical benefit rate; DLT, dose limited toxicities; PR, partial response; DMFS, distant metastasis free survival; LPFS, local progression free survival; irAEs, number of participants experiencing immune-related toxicities.

\section{Clinical experience and ongoing research}

In patients with advanced CRC in which all chemotherapy has been failed, a clinical trial of tremelimumab was conducted. It is multicentric phase 2 trial (58). Results of study did not show any improvement in survival of patients as a single agent. This showed CTLA-4 inhibitors are not much useful in CRC. Recently updated results of 74 patients treated with monotherapy of nivolumab were presented at GIT cancer symposium. 28\% patients had PD-L1 positive tumor, 16\% had BRAF mutation, $35 \%$ had KRAS mutation, 31\% had Lynch syndrome. The Disease control rate was $68.9 \%$ and overall response rate was $31.1 \%$ and median progression free survival was 9.6 months. Pembrolizumab- Deficient MMR status increases the efficacy of ICIs due to aggravated immune response (59-62). This hypothesis was checked by a phase 2 trial of pembrolizumab in deficient MMR CRC. In patients with deficient MMR the objective response rate was $40 \%$ and immune related Progression free survival was 20 weeks. These two indicators in proficient MMR were $0 \%$ and $11 \%$. This showed that deficient MMR status is predictor of efficacy of pembrolizumab. Recently multiple trials have shown the beneficial effect of pembrolizumab in CRC (61-63), this result in FDA approval of pembrolizumab 
for advanced CRC (adult and pediatric patients with unresectable or metastatic, MSI-high or deficient MMR solid tumors that have progressed following prior treatment and who have no satisfactory alternative treatment options or with MSI-H or deficient MMR CRC that has progressed following treatment with a fluoropyrimidine, oxaliplatin, and irinotecan). List of clinical trials of ICIs in CRC is shown in Table 4.

Table 4 Clinical trials of immune checkpoint inhibitors in colorectal cancers (https://clinicaltrials.gov)

\begin{tabular}{|c|c|c|c|c|c|}
\hline NCT Number & Title & Phase & Conditions & Interventions & $\begin{array}{l}\text { Outcome } \\
\text { measures }\end{array}$ \\
\hline NCT03332498 & $\begin{array}{l}\text { Pembrolizumab in combination with ibrutinib for } \\
\text { advanced, refractory colorectal cancers }\end{array}$ & 1,2 & Colorectal cancer & Pembrolizumab, ibrutinib & $\begin{array}{l}\text { Phase I: RP2D; } \\
\text { phase II: DCR }\end{array}$ \\
\hline NCT03307603 & $\begin{array}{l}\text { Yttrium90 radioembolization + nivolumab for liver } \\
+ \text { extra hepatic metastases from colorectal cancer }\end{array}$ & 1,2 & $\begin{array}{l}\text { Metastatic } \\
\text { colorectal cancer }\end{array}$ & $\begin{array}{l}\text { yttrium }-90 \\
\text { radioembolization, } \\
\text { nivolumab }\end{array}$ & $\begin{array}{l}\text { Phase I: SAE, } \\
\text { PFS, OS, Phase } \\
\text { II: RS, PFS, OS }\end{array}$ \\
\hline NCT03259867 & $\begin{array}{l}\text { Combination of TATE and PD-1 inhibitor in liver } \\
\text { cancer and colorectal neoplasms }\end{array}$ & 2 & $\begin{array}{l}\text { Hepatocellular, } \\
\text { colorectal } \\
\text { Neoplasms }\end{array}$ & $\begin{array}{l}\text { Nivolumab, pembrolizumab } \\
\text { trans-arterial tirapazamine } \\
\text { embolization }\end{array}$ & $\begin{array}{l}\text { RR, ORR, DOR, } \\
\text { PFS, OS }\end{array}$ \\
\hline NCT03206073 & $\begin{array}{l}\text { A phase } \mathrm{I} / \mathrm{II} \text { study of Pexa-Vec oncolytic virus in } \\
\text { combination with immune checkpoint inhibition in } \\
\text { refractory colorectal cancer }\end{array}$ & 1,2 & Colorectal cancer & $\begin{array}{l}\text { Durvalumab, } \\
\text { tremelimumab, Pexa-Vec }\end{array}$ & LAEF \\
\hline NCT03202758 & $\begin{array}{l}\text { Evaluation of the safety and the tolerability of } \\
\text { Durvalumab plus Tremelimumab combined with } \\
\text { folfox in metastatic colorectal cancer }\end{array}$ & 1,2 & $\begin{array}{l}\text { Colorectal cancer } \\
\text { metastatic }\end{array}$ & $\begin{array}{l}\text { Durvalumab, tremelimumab } \\
\text { and FOLFOX }\end{array}$ & EOS \\
\hline NCT03182894 & $\begin{array}{l}\text { Epacadostat in combination with Pembrolizumab } \\
\text { and Azacitidine in subjects with metastatic } \\
\text { colorectal cancer }\end{array}$ & 1,2 & $\begin{array}{l}\text { Metastatic } \\
\text { colorectal cancer }\end{array}$ & $\begin{array}{l}\text { Epacadostat (INCB024360) } \\
\text { in combination with } \\
\text { pembrolizumab (MK-3475) } \\
\text { and azacitidine (VIDAZA) }\end{array}$ & $\begin{array}{l}\text { Phase Ib: RP2D; } \\
\text { phase II: ORR, } \\
\text { PFS, DOR, OS }\end{array}$ \\
\hline NCT03104439 & $\begin{array}{l}\text { Nivolumab and ipilimumab and radiation therapy } \\
\text { in MSS and MSI high colorectal and pancreatic } \\
\text { cancer }\end{array}$ & 2 & $\begin{array}{l}\text { Colorectal cancer, } \\
\text { pancreatic cancer }\end{array}$ & $\begin{array}{l}\text { Nivolumab, ipilimumab, } \\
\text { radiation Therapy }\end{array}$ & $\begin{array}{l}\text { DCR, MOS, } \\
\text { MPFS }\end{array}$ \\
\hline NCT03095781 & $\begin{array}{l}\text { Pembrolizumab and XL888 in patients with advan } \\
\text { ced gastrointestinal cancer }\end{array}$ & 1 & $\begin{array}{l}\text { Colorectal } \\
\text { adenocarcinoma, } \\
\text { and } 38 \text { more }\end{array}$ & XL888, pembrolizumab & $\begin{array}{l}\text { ORR, OS, PFS, } \\
\text { DOR }\end{array}$ \\
\hline NCT03026140 & $\begin{array}{l}\text { Nivolumab, ipilimumab and COX2-inhibition in } \\
\text { early stage colon cancer: an unbiased approach } \\
\text { for signals of sensitivity }\end{array}$ & 2 & Colon carcinoma & $\begin{array}{l}\text { Nivolumab, ipilimumab, } \\
\text { celecoxib } 200 \text { mg }\end{array}$ & IAC, AE, RFS \\
\hline
\end{tabular}

Table 4 (continued) 
Table 4 (continued)

\begin{tabular}{|c|c|c|c|c|c|}
\hline NCT Number & Title & Phase & Conditions & Interventions & $\begin{array}{l}\text { Outcome } \\
\text { measures }\end{array}$ \\
\hline NCT03007407 & $\begin{array}{l}\text { Study of durvalumab and tremelimumab after } \\
\text { radiation for microsatellite stable metastatic } \\
\text { colorectal cancer progressing on chemotherapy }\end{array}$ & 2 & $\begin{array}{l}\text { Colorectal cancer } \\
\text { metastatic }\end{array}$ & Durvalumab, tremelimumab & ORR, AE \\
\hline NCT02981524 & $\begin{array}{l}\text { Phase } 2 \text { study of GVAX (with CY) and } \\
\text { pembrolizumab in MMR-P advanced colorectal } \\
\text { cancer }\end{array}$ & 2 & $\begin{array}{l}\text { Metastatic } \\
\text { colorectal cancer }\end{array}$ & CY, GVAX, pembrolizumab & ORR, OS, PFS \\
\hline NCT02860546 & $\begin{array}{l}\text { A study evaluating TAS-102 plus nivolumab in } \\
\text { patients with MSS CRC }\end{array}$ & 2 & $\begin{array}{l}\text { Refractory } \\
\text { metastatic } \\
\text { colorectal cancer }\end{array}$ & TAS-102 nivolumab & $\begin{array}{l}\text { irORR, ORR, } \\
\text { PFS, DCR, OS }\end{array}$ \\
\hline NCT02837263 & $\begin{array}{l}\text { Pi Pembro in combination with stereotactic body } \\
\text { radiotherapy for liver metastatic colorectal cancer }\end{array}$ & 1 & Colorectal cancer & $\begin{array}{l}\text { Stereotactic body } \\
\text { radiotherapy (SBRT), } \\
\text { pembrolizumab }\end{array}$ & RR, DFS, OS \\
\hline NCT02754856 & $\begin{array}{l}\text { Tremelimumab (anti-CTLA-4) plus durvalumab } \\
\text { (MEDI4736) (anti-PD-L1) in the treatment of } \\
\text { resectable colorectal cancer liver metastases }\end{array}$ & 1 & $\begin{array}{l}\text { Colorectal cancer, } \\
\text { liver metastases }\end{array}$ & $\begin{array}{l}\text { Tremelimumab, MEDI } 4736 \text {, } \\
\text { liver resection }\end{array}$ & RFS \\
\hline NCT02713373 & $\begin{array}{l}\text { Cetuximab and pembrolizumab in treating } \\
\text { patients with colorectal cancer that is metastatic } \\
\text { or cannot be removed by surgery }\end{array}$ & 1,2 & $\begin{array}{l}\text { Colorectal } \\
\text { carcinoma }\end{array}$ & Cetuximab, pembrolizumab & AE, PFS, OS, RR \\
\hline NCT02600949 & $\begin{array}{l}\text { Peptide vaccine in advanced pancreatic ductal } \\
\text { adenocarcinoma or colorectal adenocarcinoma }\end{array}$ & 1 & $\begin{array}{l}\text { Pancreatic cancer, } \\
\text { colorectal cancer }\end{array}$ & Pembrolizumab & PFS, AE \\
\hline NCT02375672 & $\begin{array}{l}\text { Study of pembrolizumab in combination with } \\
\text { chemotherapy for patients with advanced } \\
\text { colorectal cancer }\end{array}$ & 2 & Colorectal cancer & $\begin{array}{l}\text { Pembrolizumab, } \\
\text { mFOLFOX6 }\end{array}$ & $\begin{array}{l}\text { MPFS, ORR, OS, } \\
\text { AE, DCR }\end{array}$ \\
\hline NCT02314169 & $\begin{array}{l}\text { Nivolumab in treating patients with refractory } \\
\text { metastatic anal canal cancer }\end{array}$ & 2 & Anal canal & Nivolumab & $\begin{array}{l}\text { ORR, AE, OS, } \\
\text { PFS }\end{array}$ \\
\hline NCT02060188 & $\begin{array}{l}\text { An investigational immuno-therapy study of } \\
\text { nivolumab, and nivolumab in combination with } \\
\text { other anti-cancer drugs, in colon cancer that has } \\
\text { come back or has spread }\end{array}$ & 2 & Colorectal cancer & $\begin{array}{l}\text { Ipilimumab, nivolumab, } \\
\text { cobimetinib, daratumumab, } \\
\text { anti-LAG-3 antibody }\end{array}$ & ORR \\
\hline
\end{tabular}

DCR, disease control rate; AE, adverse events; SAE, serious adverse events; RP2D, recommended phase II dose; PFS, progression free survival; OS, overall survival; ORR, overall Response rate; RR, response rate; DOR, duration of Response; DLT, incidence of dose, limiting toxicities; CR, complete response; DFS, Disease free survival; CFS, colostomy-free survival; IOT, incidence of toxicities; STE, severe toxicity interval; LAEF, list of adverse event frequency; EOS, evaluation of the safety; PD, pharmacodynamics; MPFS, median progression free survival; MOS, median overall survival; IAC, immune activating capacity; RFS, relapse free survival; irORR, immune-related overall response rate; TEAE, treatment-emergent adverse events; PK, pharmacokinetics; irPFS, immune related progression free survival. 


\section{Future of CRC}

Combination therapy of ICIs-Active studies for combination therapies of ICIs are study of binimetinib + nivolumab with or without ipilimumab in patients with metastatic CRC with RAS mutation (NCT03271047), evaluation of the safety and the tolerability of durvalumab plus tremelimumab combined with FOLFOX in metastatic CRC (NCT03202758).

\section{ICIs with chemotherapy}

Active studies for combination of chemotherapy with ICIs are Epacadostat in combination with pembrolizumab and azacitidine in subjects with metastatic CRC (NCT03182894), olaptesed (NOX-A12) alone and in combination with pembrolizumab in CRC (NCT03168139).

\section{ICIs with radiotherapy}

Active studies for combination of ICIs with radiotherapy are nivolumab and ipilimumab and radiation therapy in MSS and MSI high colorectal and pancreatic cancer (NCT03104439), pembrolizumab in combination with stereotactic body radiotherapy for liver metastatic CRC (NCT02837263).

\section{ICIs with vaccine}

Active study for combination of ICIs with vaccine is phase 2 study of GVAX and pembrolizumab in MMR-p CRC (NCT02981524).

\section{Conclusions}

With ICIs, it's a beginning of new era for cancer treatment. By enhancing the immune system, it helps in degradation of cancer cells. After showing significant response in treatment of advanced melanoma, NSCLC, renal cancer now they are being tried in other catastrophic malignancies. GIT malignancies are extremely lethal, generally diagnosed in advanced stages and there are not much therapeutic options. ICIs in initial phases have shown promising effect in management of GIT tumors. Further research is going on ICIs individual and combination therapy with vaccines, chemotherapy, radiation therapy and surgical resection. Till now results are promising, if clinically proven beneficial, they will be a valuable tool in our armamentarium.

\section{Acknowledgements}

Special thanks to Dr Manisha Dhananjaya.

\section{Footnote}

Conflicts of Interest: The author has no conflicts of interest to declare.

\section{References}

1. Hodi FS, O'Day SJ, McDermott DF, et al. Improved survival with ipilimumab in patients with metastatic melanoma. N Engl J Med 2010;363:711-23.

2. Brahmer JR, Tykodi SS, Chow LQ, et al. Safety and activity of anti-PD-L1 antibody in patients with advanced cancer. N Engl J Med 2012;366:2455-65.

3. Ferlay J, Soerjomataram I, Ervik M, et al. GLOBOCAN 2012 v1.0. Cancer Incidence and Mortality Worldwide: IARC CancerBase No. 11 [Internet]. Lyon, France: International Agency for Research on Cancer; 2013. Available online: http://globocan.iarc.fr

4. Wagner AD, Grothe W, Haerting J, et al. Chemotherapy in advanced gastric cancer: a systematic review and meta-analysis based on aggregate data. J Clin Oncol 2006;24:2903-9.

5. Cunningham D, Starling N, Rao S, et al. Capecitabine and oxaliplatin for advanced esophagogastric cancer. $\mathrm{N} \mathrm{Engl} \mathrm{J}$ Med 2008;358:36-46.

6. Wagner AD, Unverzagt S, Grothe W, et al. Chemotherapy for advanced gastric cancer. Cochrane Database Syst Rev 2010;3:CD004064.

7. Bang YJ, Van Cutsem E, Feyereislova A, et al. Trastuzumab in combination with chemotherapy versus chemotherapy alone for treatment of HER2-positive advanced gastric or gastro-oesophageal junction cancer (ToGA): a phase 3, open-label, randomised controlled trial. Lancet 2010;376:687-97.

8. Fuchs CS, Tomasek J, Yong CJ, et al. Ramucirumab monotherapy for previously treated advanced gastric orgastro-oesophageal junction adenocarcinoma (REGARD): an international, randomised, multicentre, placebocontrolled, phase 3 trial. Lancet 2014;383:31-9.

9. Zou W, Chen L. Inhibitory B7-family molecules in the tumour microenvironment. Nat Rev Immunol 2008;8:467-77

10. Rozali EN, Hato SV, Robinson BW, et al. Programmed death ligand 2 in cancer-induced immune suppression. Clin Dev Immunol 2012;2012:656340.

11. Sznol M, Chen L. Antagonist antibodies to PD-1 and B7$\mathrm{H} 1$ (PD-L1) in the treatment of advanced human cancer. Clin Cancer Res 2013;19:1021-34.

12. Dong H, Strome SE, Salomao DR, et al. Tumor-associated 
B7-H1 promotes T-cell apoptosis: a potential mechanism of immune evasion. Nat Med 2002;8:793-800.

13. Thompson RH, Dong H, Kwon ED. Implications of B7-H1 expression in clear cell carcinoma of the kidney for prognostication and therapy. Clin Cancer Res 2007;13:709s-15s.

14. Konishi J, Yamazaki K, Azuma M, et al. B7-H1 expression on non-small cell lung cancer cells and its relationship with tumor-infiltrating lymphocytes and their PD-1 expression. Clin Cancer Res 2004;10:5094-100.

15. Ohigashi Y, Sho M, Yamada Y, et al. Clinical significance of programmed death-1 ligand-1 and programmed death-1 ligand-2 expression in human esophageal cancer. Clin Cancer Res 2005;11:2947-53.

16. Wu C, Zhu Y, Jiang J, et al. Immunohistochemical localization of programmed death-1 ligand-1 (PD-L1) in gastric carcinoma and its clinical significance. Acta Histochem 2006;108:19-24.

17. Nosho K, Baba Y, Tanaka N, et al. Tumour-infiltrating T-cell subsets, molecular changes in colorectal cancer, and prognosis: cohort study and literature review. J Pathol 2010;222:350-66.

18. Zhang L, Conejo-Garcia JR, Katsaros D, et al. Intratumoral $\mathrm{T}$ cells, recurrence, and survival in epithelial ovarian cancer. N Engl J Med 2003;348:203-13.

19. Lee HJ, Seo JY, Ahn JH, et al. Tumor-Associated Lymphocytes Predict Response to Neoadjuvant Chemotherapy in Breast Cancer Patients. J Breast Cancer 2013;16:32-9.

20. Rahir G, Moser M. Tumor microenvironment and lymphocyte infiltration. Cancer Immunol Immunother 2012;61:751-9.

21. DuPage M, Mazumdar C, Schmidt LM, et al. Expression of tumour-specific antigens underlies cancer immunoediting. Nature 2012;482:405-9.

22. Matsushita H, Vesely MD, Koboldt DC, et al. Cancer exome analysis reveals a T-cell-dependent mechanism of cancer immunoediting. Nature 2012;482:400-4.

23. Doi T, Piha-Paul SA, Jalal SI, et al. Updated results for the advanced esophageal carcinoma cohort of the phase $1 \mathrm{~b}$ KEYNOTE-028 study of pembrolizumab. J Clin Oncol 2016;34:abstr 7.

24. Muro K, Bang YJ, Shankaran V, et al. Relationship between PD-L1 expression and clinical outcomes in patients with advanced gastric cancer treated with the anti-PD-1 monoclonal antibody pembrolizumab in KEYNOTE-012. J Clin Oncol 2015;33:abstr 3.

25. Mantovani A, Allavena P, Sica A, et al. Cancer-related inflammation. Nature 2008;454:436-44.

26. Grivennikov SI, Greten FR, Karin M. Immunity, inflammation, and cancer. Cell 2010;140:883-99.

27. Llovet JM, Ricci S, Mazzaferro V, et al. Sorafenib in advanced hepa- tocellular carcinoma. N Engl J Med 2008;359:378-90.

28. Ormandy LA, Hillemann T, Wedemeyer H, et al. Increased populations of regulatory $\mathrm{T}$ cells in periph- eral blood of patients with hepatocellular carcinoma. Cancer Res 2005;65:2457-64.

29. Chen KJ, Lin SZ, Zhou L, et al. Selective recruitment of regulatory T cell through CCR6-CCL20 in hepatocellular carcinoma fosters tumor progression and predicts poor prognosis. PLoS One 2011;6:e24671.

30. Gao Q, Qiu SJ, Fan J, et al. Intratumoral balance of regulatory and cyto- toxic $\mathrm{T}$ cells is associated with prognosis of hepatocellular carcinoma after resection. J Clin Oncol 2007;25:2586-93.

31. Hoechst B, Voigtlaender T, Ormandy L, et al. Myeloid derived sup- pressor cells inhibit natural killer cells in patients with hepatocellular carcinoma via the NKp30 receptor. Hepatology 2009;50:799-807.

32. Alisa A, Ives A, Pathan AA, et al. Analysis of CD4+ T-cell responses to a novel alpha-fetoprotein-derived epitope in hepatocellular carcinoma patients. Clin Cancer Res 2005;11:6686-94.

33. Zabala M, Lasarte JJ, Perret C, et al. Induction of immunosuppressive molecules and regulatory $\mathrm{T}$ cells counteracts the antitumor effect of interleukin-12-based gene therapy in a transgenic mouse model of liver cancer. J Hepatol 2007;47:807-15.

34. Greten TF, Ormandy LA, Fikuart A, et al. Low-dose cyclophospha- mide treatment impairs regulatory $\mathrm{T}$ cells and unmasks AFP-speci c CD4+ T-cell responses in patients with advanced HCC. J Immunother 2010;33:211-8.

35. El-Khoueiry A, Melero I, Crocenzi TS. Phase I/II safety and antitumor activity of nivolumab in patients with advanced hepatocellular carcinoma (HCC): CA209-040. J Clin Oncol 2015;33:abstr LBA101.

36. Ferlay J, Soerjomataram I, Dikshit R, et al. Cancer incidence and mortality worldwide: sources, methods and major patterns in GLOBOCAN 2012. Int J Cancer 2015;136:E359-86.

37. Howlader N, Noone AM, Krapcho M, et al. SEER Cancer Statistics Review, 1975-2013, National Cancer Institute. Bethesda, MD, 2016. Available online: http://seer.cancer. gov/csr/1975_2013/ 
38. Hidalgo M, Cascinu S, Kleeff J, et al. Addressing the challenges of pancreatic cancer: future directions for improving outcomes. Pancreatology 2015;15:8-18.

39. Royal RE, Levy C, Turner K, et al. Phase 2 trial of single agent Ipilimumab (anti-CTLA-4) for locally advanced or metastatic pancreatic adenocarcinoma. J Immunother 2010;33:828-33

40. Le DT, Lutz E, Uram JN, et al. Evaluation of ipilimumab in combination with allogeneic pancreatic tumor cells transfected with a GM-CSF gene in previously treated pancreatic cancer. J Immunother 2013;36:382-9.

41. Torre LA, Bray F, Siegel RL, et al. Global cancer statistics, 2012. CA Cancer J Clin 2015;65:87.

42. Siegel RL, Miller KD, Jemal A. Cancer Statistics, 2017. CA Cancer J Clin 2017;67:7.

43. Bilgin B, Sendur MA, Bulent Akinci M, et al. Targeting the PD-1 pathway: A new hope for gastrointestinal cancers. Curr Med Res Opin 2017;33:749-59.

44. Haggar FA, Boushey RP. Colorectal cancer epidemiology: Incidence, mortality, survival, and risk factors. Clin. Colon Rectal Surg 2009;22:191-7.

45. Jasperson KW, Tuohy TM, Neklason DW, et al. Hereditary and familial colon cancer. Gastroenterology 2010;138:2044-58.

46. Lynch HT, de la Chapelle A. Hereditary colorectal cancer. N Engl J Med 2003;348:919-32.

47. Abdulovic AL, Hile SE, Kunkel TA, et al. The in vitro fidelity of yeast DNA polymerase delta and polymerase epsilon holoenzymes during dinucleotide microsatellite DNA synthesis. DNA Repair 2011;10:497-505.

48. Kastrinos F, Ojha RP, Leenen C, et al. Comparison of prediction models for Lynch Syndrome among individuals with colorectal cancer. J Natl Cancer Inst 2015;108:djv308.

49. Hemminki A, Peltomaki P, Mecklin JP, et al. Loss of the wild type MLH1 gene is a feature of hereditary nonpolyposis colorectal cancer. Nat Genet 1994;8:405-10.

50. Veigl ML, Kasturi L, Olechnowicz J, et al. Biallelic inactivation of hMLH1 by epigenetic gene silencing, a novel mechanism causing human MSI cancers. Proc Natl Acad Sci U S A 1998;95:8698-702.

51. Timmermann B, Kerick M, Roehr C, et al. Somatic mutation profiles of MSI and MSS colorectal cancer identified by whole exome next generation sequencing and bioinformatics analysis. PLoS One 2010;5:e15661.

52. Schumacher TN, Schreiber RD. Neoantigens in cancer immunotherapy. Science 2015;348:69-74.

53. Galon J, Costes A, Sanchez-Cabo F, et al. Type, density, and location of immune cells within human colorectal tumors predict clinical outcome. Science 2006;313:1960-4.

54. Quinn E, Hawkins N, Yip YL, et al. CD103+ intraepithelial lymphocytes-A unique population in microsatellite unstable sporadic colorectal cancer. Eur J Cancer 2003;39:469-75.

55. Banerjea A, Ahmed S, Hands RE, et al. Colorectal cancers with microsatellite instability display mRNA expression signatures characteristic of increased immunogenicity. Mol Cancer 2004;3:21.

56. Phillips SM, Banerjea A, Feakins R, et al. Tumourinfiltrating lymphocytes in colorectal cancer with microsatellite instability are activated and cytotoxic. Br J Surg 2004;91:469-75.

57. Saeterdal I, Bjorheim J, Lislerud K, et al. Frameshiftmutation-derived peptides as tumor-specific antigens in inherited and spontaneous colorectal cancer. Proc. Natl. Acad. Sci. USA 2001;98:13255-60.

58. Chung KY, Gore I, Fong L, et al. Phase II study of the anti-cytotoxic T-lymphocyte-associated antigen 4 monoclonal antibody, tremelimumab, in patients with refractory metastatic colorectal cancer. J Clin Oncol 2010;28:3485-90.

59. Le DT, Uram JN, Wang H, et al. PD-1 blockade in tumors with mismatch-repair deficiency. N Engl J Med 2015;372:2509-20.

60. Muro K, Chung HC, Shankaran V, et al. Pembrolizumab for patients with PD-L1-positive advanced gastric cancer (KEYNOTE-012): A multicentre, open-label, phase 1b trial. Lancet Oncol 2016;17:717-26.

61. Nanda R, Chow LQ, Dees EC, et al. Pembrolizumab in patients with advanced triple-negative breast cancer: Phase Ib KEYNOTE-012 study. J Clin Oncol 2016;34:2460-7.

62. Plimack ER, Bellmunt J, Gupta S, et al. Safety and activity of pembrolizumab in patients with locally advanced or metastatic urothelial cancer (KEYNOTE-012): A nonrandomised, open-label, phase $1 \mathrm{~b}$ study. Lancet Oncol 2017;18:212-20.

63. Diaz L, Marabelle A, Delord J, et al. Pembrolizumab therapy for microsatellite instability high (MSI-H) colorectal cancer (CRC) and non-CRC. J Clin Oncol 2017;35:3071.

Cite this article as: Jindal V. Immune checkpoint inhibitors in gastrointestinal malignancies. J Gastrointest Oncol 2018;9(2):390-403. doi: 10.21037/jgo.2018.01.03 